\title{
IS CULTURAL INFLUENCE AN ATTRIBUTE FOR KNOWLEDGE MANAGEMENT AND DECISION MAKING?
}

\author{
Robert Joseph Skovira, Robert Morris University, Pittsburgh PA, USA skovira@rmu.edu \\ Frederick G. Kohun, Robert Morris University, Pittsburgh PA, USA kohun@rmu.edu \\ Valdimir Burčik, Comenius University, Bratislava, Slovakia burcik@ilearn.sk \\ Agnesa Hiczérová, Comenius University, Bratisilava, Slovakiahiczerova1@uniba.sk
}

\begin{abstract}
Geert Hofstede's work on national culture and its characteristic dimensions have been the subject to discussion and debate since its inception in the late 1970's. While his notion may not be all encompassing and methodologically generalizable, it has been repeatedly revisited and discussed by scholars and academics throughout the world. Why is this notion subject to so much discussion and debate when it has been so scrutinized and criticized? It is from this perspective that this paper reexamines Hofstede's cultural model focusing on inherent yet critical cultural sub determinants and its culturally determined bounded rationality. A model is developed based on a culturally bound moral program. Cultural bias is an important factor in a global networked economy and is proposed as a consideration for managerial decision making. Empirical data from Mexico, Slovakia, and the USA demonstrate change within the national cultural aggregate over time.
\end{abstract}

Keywords: Hofstede, cultural model, global management, cultural dimensions, cultural bounded rationality, social environments, moral social circles, mental programs

\section{INTRODUCTION}

Geert Hofstede's work on national culture and its characteristic dimensions have been the subject to discussion and debate since its inception in the late 1970's. While his notion may not be all encompassing and methodologically generalizable, it has been repeatedly revisited and discussed by scholars and academics throughout the world. Why is this notion subject to so much discussion and debate when it has been so scrutinized and criticized? The answer is bound by our individual irrefutable bounding by cultural rationality. While many studies have explored cultural determinants as a basis for decision making at the individual, organizational, professional, ethnic, and national levels, whether or not it is universally and meaningfully measureable, there is a cultural imprint that prevails (Kohun, Skovira \& Burcik, 2012). As best described by McSweeny in 2003, when "he [Hofstede] hypothesizes that culture displays a geographic or territorial uniqueness, is nationally shared from a statistical average vantage point, is inherently mentally subjective, is determinate as the influence, displays identifiable characteristics and predictable consequences, and is enduring" (McSweeney, 2003, p.7 in Kohun, Skovira \& Burcik, 2012). It is from this perspective that this paper reexamines Hofstede's cultural model focusing on inherent yet critical cultural sub determinants and its culturally determined bounded rationality. Cultural bias is an important factor in a global networked economy and is proposed as a consideration for managerial decision making.

\section{CRITICAL ASSESSMENT}

McSweeny (2003) has criticized Hofstede's cultural model as being "subjective" and "implicit" (91). And this may be a problem, unless you believe culture is a consequence of cognition (Straus \& Quinn, 1997). McSweeney's criticism is based taking Hofstede's work in context. He bases his discussion on the underlying considerations of Hofstede's initial IBM study that was directed not to identify national culture but rather to contend with a global IBM declining morale problem. He also discussed how Hofstede's cultural determinant or dimensions were derived from other social scientists before him. Also the problem associated with the danger of generalizing form aggregated data questions any overbearing conclusions. Nevertheless, while the criticisms are valid and directed, they do not diminish the purpose of Hofstede's work as a focal point for study of cultural influence. 


\section{THEORIES ARE CULTURALLY BOUND}

Another significant issue is the stated position that theories and generators of theories are culturally bound, so Hofstede (2010: 307, 1994: 4) [For ease of use, we have decided to use Hofstede even when he has co-authors; for example the 2010 edition is co-authored with his son and with Minkov.] has repeatedly reminded us, and, of course, the researchers who have applied Hofstede's notions are also culturally contextualized (2010: 339).

When we as researchers look at the results of surveys, do we see felt preferences, or do we see moral circles and attending social circles, groups, or do we see mental programs? In any case, are we looking at difference between social groups, or between social environments? These may define the sub determinants that form the basis of cultural identity.

\section{DEFINING CULTURE}

Hofstede defines culture rather consistently across three social environments possible out of a multitude of social environments. These three social environments are the national, the organizational, and the occupational. These social environments are the spaces where individuals are collectively programmed into those patterns of emotion, cognition, and acting are forms of adaptation to the problems encountered in these environments (Hofstede, Hofstede \& Minkov 2010: 6, 344, 368). Hofstede matches each social environment with a set of value dimensions.

\section{ESSAY'S PROBLEM}

We are not writing that Hofstede does not have a definition of culture; he does. But except for McSweeny, researchers do not seem to pay attention.

The problem is: what is Hofstede's idea of culture which under-pins the survey questions? In most of the research, the focus has been on the dimensions, almost to the exclusion of any awareness of the concept of culture. Also, there has seemed to be a glossing over of Hofstede's idea of cultural boundedness not unlike H. Simon's idea of bounded rationality. Therefore, how can Hofstede's cultural dimensions be used in the context of knowledge management and decision making given the empirical evidence that demonstrates that differences do exist which can be explained by culture.

\section{CULTURAL MODEL DESCRIBED}

Culture is a term that encompasses Hofstede's ideas of practices and values. And these are interesting terms. Hofstede (2010) does define culture as "the collective programming of mind" (6) as differentiated of social groups. Then the questions of what is the basis of this "collective programming of mind" and why does it persist become the basis of this model. The model thereby proposed consists of the following basic parts: mental programs, moral social circles, social games and rules, and practices and values.

\section{MENTAL PROGRAMS}

The emotional, cognitive, and behavioral configurations which constitute a person's subjective awareness are "mental programs" (Hofstede, Hofstede \& Minkov 2010: 4,5). In other conversations, we might hear about habits, dispositions, see P. Bourdieu, or attitudes. The source of such gestation, or patterns is the "immediate" social environment (Hofstede, Hofstede \& Minkov 2010: 5). This social environment is the context wherein such patterns, mental programs, mental models (see D. Norman) or scripts are inculcated, or learned. Mental programs are expressive of moral circles and therefore social circles. Mental programs, mind or culture (ethos) are sourced in moral and social circles. Mental programs differentiate members of social groups. 
Dimensions of societal, organizational, and occupations social environments are expressive of mental programs. Societies, organization, and occupations are social environments. Culture as mental programs, or emotional, cognitive, and action patterns is derived from or generated from social environments. These dimensions have been represented and measured typically through the dimensions proposed by Hofstede in his work. (See table 1)

Table 1. Mental Program [National] Attributes

\begin{tabular}{|rll|}
\hline 1. & Power Distance & (PDI) \\
\hline 2. & Individualism / Collectivism & (IDV) \\
\hline 3. & Masculinity / Feminity & (MAS) \\
\hline 4. & Uncertainty Avoidance & (UAI) \\
\hline 5. & Long - Term / Short - Term Orientation & (LTO) \\
\hline 6. & Indulgence / Restraint & (IVR) \\
\hline
\end{tabular}

Mental programs collectively uncollated are configurative habits of emotion, cognition and action. The dispositions or attitudes accepted manners of interaction. They are grounded in a social environment lived-in, or in multiple social environments. These preferred forms of interaction are cultural. They are the "unwritten rules of the social game" (Hofstede, Hofstede \& Minkov 2010: 26).

\section{MORAL-SOCIAL CIRCLES}

Moral-social circles, or groups, are social environments of mental programs or cultures. Hofstede proposes a view of culture that is layered: "national," "regional," "ethnic," "religious," "linguistic," "gender," "generation," "class," "organizational," "occupational" (Hofstede, Hofstede \& Minkov 2010: 17-18). One can argue these are labels of possible moral-social circles; each will be the focus of a value system, or a belief system. Each will have a set of practices and an under-layer set of value dimension. These dimensions are Hofstede's cultural model (Hofstede, Hofstede \& Minkov 2010:31). They also act as cultural filters affecting how we see and interpret things.

\section{PRIMARY MORAL-SOCIAL CIRCLE}

The family, the primary moral and social circle (Hofstede, Hofstede \& Minkov, 2010: 12, 20), is the social space where the patterns of experience, emotional, cognitive, active, begin to be developed and fostered. The mental programs are culture (Hofstede, Hofstede \& Minkov, 2010: 5). Understanding the role of family is inherent to a functional social interaction and value system. The dimensional data empirically demonstrates these differences.

\section{SOCIAL GAMES AND RULES}

People within social environments live within social games; dwelling in a social situation means following "the unwritten rules of the social game" (Hofstede, Hofstede \& Minkov, 2010: 6). These rules are culture, or mental programs. These patterns of feelings, thinking and acting are the difference between groups, and their members. These patterns bound a "moral circle" (Hofstede, Hofstede \& Minkov 2010: 16, 12-13). "Culture is about how to be a good member of the [a] moral circle" (Hofstede, Hofstede \& Minkov 2010: 14). The moral circle and associated games can be argued to form the basis of interacting, communicating and decision making. Understanding them is necessary for successful interaction.

\section{PRACTICES AND VALUES}

Another way Hofstede writes of culture is that is a conjunction of practices and values (Hofstede, Hofstede \& Minkov 2010: 9). Values and practices are aspects of a social game; social games are forms of moral-social circles, or social environments. 
Hofstede writes of the visible part of a culture as practices (H, H \& M 2010:9). These practices are categorized as "symbols," "heroes," and "rituals" (Hofstede, Hofstede \& Minkov 2010: 8-9). These are everyday affairs and variable over time; these are what, and how, people say things, act, or feel. The symbolic affairs and things, linguistic expression, gestures, images make sense to those sharing mental programs (Hofstede, Hofstede \& Minkov 2010: 8). Things mean what they mean to people who share the same culture. A shared social environment, or culture also may provide mentors or "heroes" to be followed (Hofstede, Hofstede \& Minkov 2010: 8). Role models both explicitly and implicitly perpetuate norms and values. These kind of practices are rituals (Hofstede, Hofstede \& Minkov M 2010: 9) which are common sensible actions and language use in social environments. Practices are visible, audible, and sensible ways of being in the world; they are what people of and say, how they act, how they feel, how they think; the manner of living in a place. What makes them the visible components of a culturally bounded space is the "meanings" they survey as interpretive structures of a particular moral and social circle; as such these meanings are invisible rules of the social game (Hofstede, Hofstede \& Minkov 2010: 9).

For Hofstede, a culture is observable in the sense of these practices of its members; the sense of these practices are given by the attending non-observable meanings of values of the practices, as understood by members of the particular moral-social circle (Hofstede, Hofstede \& Minkov 2010: 9). Values are dispositions or habits of preference of interpretations of events and affairs over and against other perspectives (Hofstede, Hofstede \& Minkov 2010: 9). Values are about beliefs as a systematic attitude about things and people. While they may have an emotional charge (Hofstede, Hofstede \& Minkov 2010: 9), they also designate an ontology of patterns which integrate the details of lived experience to the invisible meanings of a shared social environment. Values are inculcated from birth, via individuals living in the interactive situation of the primary moral-social circle. They become habits of expectation; as dispositions they are non-conscious assumptions about reality. As such these values are invisible to outsiders. What people do and say and how they do and say things are signs of the non-observable values (Hofstede, Hofstede \& Minkov 2010: 11). "Values are implicit: they belong to the invisible software of our minds" (Hofstede, Hofstede \& Minkov 2010:23). These invisible meanings are "values" (Hofstede, Hofstede \& Minkov 2010: 9). It is these values that transcend individuals to form the basis of the social and cultural identity. Dimensions may be used semiotically as signals or flags for differences to delve into the culturally bounded realm of practices and values.

\section{DIMENSIONS OF VALUE}

Hofstede's focuses on a set of value dimensions for national cultural descriptions, as well as a set of value dimensions at the organizational level, and the occupational level. Hofstede argues that values are feelings. We think we understand this term. But do we? Elsewhere he uses the term emotion (emotional). according to his definition of culture, a consequence of living-in a moral-social circle, emotion is a pattern or disposition. This is a habitual rendering of a response expressing a preferred approach or way of dealing with events, affairs, and situations. A habitual way of defining the context as something familiar to one's assumptions; individuals are usually unaware of the assumptive projection (Hofstede, Hofstede \& Minkov 2010: 11). The national value dimensions are a consequence of socialization overtime into the perspective of a moral-social circle which one belongs to. According to Hofstede, the value dimensions are factually the givens of a worldview (Hofstede, Hofstede \& Minkov 2010: 20). They are parts of those networks of meanings a moral-social circle enmeshes itself in. They indicate differences between members of groups operating in the same social environment. As a consequence of inculcation, the national value dimensions, as represented and expressed, appear to be emotional, or feelings. The mental program, or mind, as individualized, reflects the patterns of a moral-social circle, or so-called culture, or a particular form of the social game. Hofstede argues that the national value dimensions are expressive of emotional patterns by members of a particular moral-social circle in symbols or rituals or practices (Hofstede, Hofstede \& Minkov 2010: 8-9). But, more to the point, values or beliefs, as unconscious habits of interaction, are "moral rules" (Hofstede, Hofstede \& Min 2010: 12) of a moral-social circle. The national value dimensions are "power distance" (Hofstede, Hofstede \& Minkov 2010: 61), an unwritten rule of the group's social game is an individual's acceptance of social place in the scheme of affairs. Another unwritten rule of a social game is "Individualism" and "collectivism" (Hofstede, Hofstede \& Minkov 2010:92); this rule appears to be about self-sufficiency or dependency. Another rule as value dimension is "masculine" and "feminine" (Hofstede, Hofstede \& Minkov 2010:140); this silent rule of behavior appears to concern the differences of styles: aggressive or concern for qualities of life. Another silent rule of mental programming is "uncertainty avoidance" (Hofstede, Hofstede \& Minkov 2010: 191); this rule is important. The value dimension of "long-term orientation" and "shortterm orientation" Hofstede, Hofstede \& Minkov 2010: 239) is an important written rule in terms of self-gratification 
and self-discipline. The value dimension of "indulgence" and "restraint" (Hofstede, Hofstede \& Minkov 2010: 281) are aspects of a cultural model concerning happiness or well-being. (See table 1).

While the organizational value dimensions appear to be independent of national cultures (if they do in fact exist), they are not. Hofstede has indicated there are at least four structural modes for organizations (according to national cultures): "pyramids, machines, markets, and families" (Hofstede, Hofstede \& Minkov 2010: 304). (See table 2).

Table 2. Organizational Value Dimensions-- Hofstede's Primary Structural Modes

\begin{tabular}{|ll|}
\hline 1. & Pyramids \\
\hline 2. & Machines \\
\hline 3. & Markets \\
\hline 4. & Families \\
\hline
\end{tabular}

The model (Table 3) also sets out, as a component, a relation of organizational type to organizational governance styles: Monarchical, Feudal, Federal, and Anarchical (Davenport, Eccles, \& Prusak, 1992; Davenport with Prusak, 1997; DeLorenzo et al., 2006). Organizational governance is about information control. In the monarchical mode of corporate governance, information ownership or control is invested in one person or in one functional area of an organization. One individual designates significance and meaning of informational items and manages the interpretive models of information application (Davenport with Prusak, 1997, p. 74). In the federal mode of corporate governance, information control is shared across organizational boundaries of functional areas. Within this kind of political frame of information use, corporate interest groups define and interpret informational flows according to their situations (Davenport with Prusak, 1997, pp. 68-72). The feudal mode of corporate governance suggests that the separate corporate entities control and manage their own information culture and behavior. A senior manager is "lord of the information" (Davenport with Prusak, 1997, pp. 72-74). In the anarchical mode, control over meaning and the significance of information is personal and individualistic. There is no common sensibility of information use (Davenport with Prusak, 1997, pp. 75-76). Political frames of information use are managerial structures of informational flows for the distribution and sharing of information from a centralized to a decentralized perspective (Kohun et al, 2013).

Table 3. Organizational Governance and Organizational Models (Kohun et al, 2013)

\begin{tabular}{|l|l|}
\hline Market & Family \\
Small-PDI, Weak-UAI & Large-PDI, Weak-UAI \\
Authority not centralized & Authority centralized \\
Work flow not structured & Work flow not structured \\
Information use not structured & Information use not structured \\
Governance: Federal & Governance: Monarchical \\
\hline Machine & Pyramid \\
Small-PDI, Strong-UAI & Large-PDI, Strong-UAI \\
Authority not centralized & Authority centralized \\
Work flow structured & Work flow structured \\
Information use structured & Information use structured \\
Governance: Feudal & Governance: Monarchical, Feudal \\
\hline
\end{tabular}

Furthermore, the value dimensions of organizational culture are "process oriented" and "result oriented" (Hofstede, Hofstede \& Minkov 2010: 354); this is a silent rule about an organizational culture's orientation to procedures or to results. The value dimension of "employee oriented" and "job oriented" (Hofstede, Hofstede \& Minkov 2010: 354) is an unwritten rule of orientation to employee benefits or to performance. The dimension of "parochial" and "professional" Hofstede, Hofstede \& Minkov 2010: 354) is a silent rule of an organizational culture of orientation to identification with the organization or with the profession. Another organizational cultural dimension is "open system" and "closed system" (Hofstede, Hofstede \& Minkov 2010: 354); this hidden rule shows up as the ease or difficulty of assimilation into organizational life. An organizational value dimension is "lose control" and "tight control" (Hofstede, Hofstede \& Minkov 2010: 354); this silent rule is about a structured and controlled environment or not. A final dimension presents a "normative" and "pragmatic" orientation (Hofstede, Hofstede \& Minkov 2010: 354); this aspect of the organizational mental program is about an orientation toward policy or to the ignoring of policy and procedures but performing to expectations. (See table 4). 
Table 4. Mental Program (Moral Social Model) Organizational Attributes

\begin{tabular}{|rl|}
\hline 1. & Progress / Result Orientation \\
\hline 2. & Employee / Job Orientation \\
\hline 3. & Parochialism / Professionalism \\
\hline 4. & Open / Closed System \\
\hline 5. & Tight / Loose Control \\
\hline 6. & Normative / Pragmatic Orientation \\
\hline
\end{tabular}

The value dimensions constituting the invisible aspect of occupational culture and "handling people" or "handling things" (Hofstede, Hofstede \& Minkov 2010: 369), "specialist" or "generalist" (Hofstede, Hofstede \& Minkov 2010: 369) "disciplined" or "independent" (Hofstede, Hofstede \& Minkov 2010: 369), "structured" or "unstructured" (Hofstede, Hofstede \& Minkov, 2010: 369), "theoretical" or "practical" (Hofstede, Hofstede \& Minkov 2010: 369), "normalcies" or "pragmatic" (Hofstede, Hofstede \& Minkov 2010: 369). (See table 5).

Table 5. Occupational Mental Program (Moral Social Circles)

\begin{tabular}{|rl|}
\hline 1. & Handling People / Handling Things \\
\hline 2. & Specialists / Generalists \\
\hline 3. & Disciplined / Independent \\
\hline 4. & Theoretical / Practical \\
\hline 5. & Normative / Pragmatic \\
\hline 6. & Structured / Unstructured \\
\hline
\end{tabular}

Each culture, in aggregate, can be argued to reflect a unique combination of attributes and dimensions that form the basis of their identity, the view of the world, and how they interpret data and information. However, individuals assessed separately would be expected to exhibit significant differences form the national aggregate. Empirical data demonstrates these differences from the aggregate values regularly published. Particularly, when analyzed with respect to attributes such as age, gender, and occupation there appears to be significant variation from national aggregate values.

\section{RESEARCH GROUPS}

We collected scores from five research groups from three countries, Mexico, USA and Slovakia - primarily from a varied university population.

Table 6. The group's demography - gender (percentage \%)

\begin{tabular}{|c|c|c|c|c|c|}
\hline & $\begin{array}{c}\text { Mexico } \\
2016 \\
\mathrm{~N}=59\end{array}$ & $\begin{array}{c}\text { SK } \\
2014 / 2015 \\
N=142\end{array}$ & $\begin{array}{c}\text { SK } \\
2016 \\
\text { N=86 }\end{array}$ & $\begin{array}{c}\text { USA } \\
2014 \\
\text { N=104 }\end{array}$ & $\begin{array}{l}\text { USA } \\
\mathbf{2 0 1 5} \\
\mathbf{N}=\mathbf{5 7}\end{array}$ \\
\hline Men & 100,0 & 21,1 & 16,28 & 76,9 & 54,4 \\
\hline Women & 0,00 & $\overline{78,9}$ & 83,72 & 23,1 & 45,6 \\
\hline All & 100,0 & 100,0 & 100,0 & 100,0 & 100,0 \\
\hline
\end{tabular}

Table number. ; $N=$ number of the respondents 
Table 7. Age (percentage \%)

\begin{tabular}{|l|c|c|c|c|c|}
\hline Age & $\begin{array}{c}\text { Mexico } \\
\mathbf{2 0 1 6} \\
\mathbf{N}=\mathbf{5 9}\end{array}$ & $\begin{array}{c}\mathbf{2 0 1 4} / \mathbf{2 0 1 5} \\
\mathbf{N}=\mathbf{1 4 2}\end{array}$ & $\begin{array}{c}\mathbf{2 0 1 6} \\
\mathbf{N}=\mathbf{8 6}\end{array}$ & $\begin{array}{c}\text { USA } \\
\mathbf{2 0 1 4} \\
\mathbf{N}=\mathbf{1 0 4}\end{array}$ & $\begin{array}{c}\text { USA } \\
\mathbf{2 0 1 5} \\
\mathbf{N}=\mathbf{5 7}\end{array}$ \\
\hline Less than 20 & 1,7 & 0,00 & 0,00 & 8,7 & 15,8 \\
\hline $\mathbf{2 0 - 2 4}$ & 25,4 & 95,1 & 93,02 & 31,7 & 71,9 \\
\hline $\mathbf{2 5 - 2 9}$ & 25,4 & 2,8 & 6,98 & 18,3 & 1,8 \\
\hline $\mathbf{3 0 - 3 4}$ & 23,7 & 1,4 & 0,00 & 14,4 & 3,5 \\
\hline $\mathbf{3 5 - 3 9}$ & 13,6 & 0,7 & 0,00 & 6,7 & 1,8 \\
\hline $\mathbf{4 0 - 4 9}$ & 8,5 & 0,00 & 0,00 & 13,5 & 5,3 \\
\hline $\mathbf{5 0 - 5 9}$ & 1,7 & 0,00 & 0,00 & 5,8 & 0,00 \\
\hline $\mathbf{6 0}$ and more & 0,00 & 0,00 & 0,00 & 1,0 & 0,00 \\
\hline All & 100,0 & 100,0 & 100,0 & 100,0 & 100,0 \\
\hline
\end{tabular}

Table number. ; $N=$ number of the respondents

Table 8. Results

\begin{tabular}{|l|r|r|r|r|r|}
\hline & $\begin{array}{c}\text { Mexico } \\
\mathbf{2 0 1 6} \\
\mathbf{N = 5 9}\end{array}$ & $\begin{array}{c}\text { SK } \\
\mathbf{2 0 1 4 / 2 0 1 5} \\
\mathbf{N = 1 4 2}\end{array}$ & $\begin{array}{c}\text { Slovakia 2016 } \\
\mathbf{N = 8 6}\end{array}$ & $\begin{array}{c}\text { USA } \\
\mathbf{2 0 1 4} \\
\mathbf{N = 1 0 4}\end{array}$ & \multicolumn{1}{c|}{$\begin{array}{c}\text { USA 2015 } \\
\text { N=57 }\end{array}$} \\
\hline PDI & $-1,19$ & 20,63 & 20,17 & 8,75 & 25,44 \\
\hline IDV & 4,15 & 45,35 & 37,44 & $-0,34$ & $-4,29$ \\
\hline MAS & 18,98 & 35 & 3,66 & & \\
\hline UAI & $-34,74$ & $-71,87$ & 30,83 & $-31,87$ & $-22,19$ \\
\hline LTO & 6,10 & $-4,58$ & 7,73 & $-52,6$ & $-59,29$ \\
\hline IVR & 71,86 & 93,99 & $-47,33$ & 64,95 & 65,35 \\
\hline
\end{tabular}

Table number. ; $N=$ number of the respondents

Hypothesis 1: We expect a significant difference between the group scores from Mexico, Slovakia, and the USA.

Table 9. Index score for the countries and year of survey

\begin{tabular}{|l|r|r|r|r|r|}
\hline \multicolumn{7}{|c|}{ Countries index } \\
& $\begin{array}{c}\text { Mexico } \\
\mathbf{2 0 1 6} \\
\mathbf{N = 5 9}\end{array}$ & $\begin{array}{c}\text { SK } \\
\mathbf{2 0 1 4 / 2 0 1 5} \\
\mathbf{N = 1 4 2}\end{array}$ & $\begin{array}{c}\text { Slovakia 2016 } \\
\text { N=86 }\end{array}$ & $\begin{array}{c}\text { USA } \\
\mathbf{2 0 1 4} \\
\mathbf{N = 1 0 4}\end{array}$ & $\begin{array}{c}\text { USA 2015 } \\
\text { N=57 }\end{array}$ \\
\hline $\boldsymbol{P D I}$ & $-1,19$ & 20,63 & 20,17 & 8,75 & 25,44 \\
\hline $\boldsymbol{I D V}$ & 4,15 & 45,35 & 37,44 & $-0,34$ & $-4,29$ \\
\hline $\boldsymbol{M A S}$ & 18,98 & 35 & 3,66 & - & - \\
\hline $\boldsymbol{U A I}$ & $-34,74$ & $-71,87$ & 30,83 & $-31,87$ & $-22,19$ \\
\hline $\boldsymbol{L T O}$ & 6,10 & $-4,58$ & 7,73 & $-52,6$ & $-59,29$ \\
\hline $\boldsymbol{I V R}$ & 71,86 & 93,99 & $-47,33$ & 64,95 & 65,35 \\
\hline
\end{tabular}


Table 10. Mean Ranks

\begin{tabular}{|c|c|c|c|c|c|}
\hline \multicolumn{6}{|c|}{ Mean Ranks } \\
\hline & $\begin{array}{c}\text { Mexico } \\
2016 \\
\text { N=59 }\end{array}$ & $\begin{array}{c}\text { SK } \\
2014 / 2015 \\
N=142\end{array}$ & $\begin{array}{c}\text { Slovakia } \\
2016 \\
\mathrm{~N}=86\end{array}$ & $\begin{array}{c}\text { USA } \\
2014 \\
\mathrm{~N}=104\end{array}$ & $\begin{array}{c}\text { USA } 2015 \\
\mathbf{N}=\mathbf{5 7}\end{array}$ \\
\hline$P D I$ & 184,24 & 235,88 & 240,49 & 204,28 & 250,53 \\
\hline$I D V$ & 185,31 & 284,75 & 263,45 & 165,99 & 162,94 \\
\hline$M A S$ & 141,19 & 163,12 & 114,36 & - & - \\
\hline $\boldsymbol{U A I}$ & 211,49 & 149,78 & 355,74 & 216,87 & 240,03 \\
\hline LTO & 277,19 & 255,35 & 278,44 & 151,79 & 144,39 \\
\hline$I V R$ & 254,43 & 283,36 & 72,40 & 254,30 & 238,41 \\
\hline
\end{tabular}

Table 11. Test Statistics

\begin{tabular}{|l|r|r|r|r|r|r|}
\hline \multicolumn{7}{|c|}{ Test Statistics, $^{\text {, }}$} \\
\hline & \multicolumn{1}{|c|}{ PDI } & \multicolumn{1}{c|}{ IDV } & \multicolumn{1}{c|}{ MAS } & \multicolumn{1}{c|}{ UAI } & \multicolumn{1}{c|}{ LTO } & \multicolumn{1}{c|}{ IVR } \\
\hline $\begin{array}{l}\text { Chi- } \\
\text { Square }\end{array}$ & 13,006 & 81,941 & 19,329 & 137,649 & 87,575 & 155,053 \\
\hline $\boldsymbol{d f}$ & & & & & & 4 \\
\hline $\begin{array}{l}\text { Asymp. } \\
\text { Sig. }\end{array}$ &, 011 &, 000 &, 000 &, 000 &, 000 &, 000 \\
\hline $\begin{array}{l}\text { a. Kruskal-Wallis Test } \\
\text { b. Grouping Variable: nationality }\end{array}$ & & & & & \\
\hline
\end{tabular}

Kruskal-Wallis test shows significant statistic difference $(\mathrm{p}<0,05)$ differences in all cultural dimensions. Hypothesis 1 , is verified.

\section{FINAL THOUGHTS}

While there is much debate with the work of Hofstede and those that have tried to both test and adapt his notion of culture, the model he suggests is useful as a guide to understanding and working with different social groups. The social groups can be national, ethnic, organizational, professional, or religious based, yet each group shares generally common attributes as discussed above. In managing within a networked economy, it is essential to consider culture nuance, differentiation, and identity as part of communication, negotiation, information exchange, and vision. Figure 1 below provides a visual summary of the factors, influences, and attributes that form the basis of a particular cultural model.

In a networked global economy cultural nuances may be overt or hidden. Considerations such as short term or long term orientation radically affect negotiation and decision making. While organizational culture may be argued to prevail over national or ethnic culture - the 1970's IBM Hofstede study revealed that even with a homogeneous international organizational and professional population, there were significant differences in cultural markers as reflected through the mental program attribute indexes. While managerial decisions may be global in nature, the effects and considerations are rooted locally and individually - as a frame of reference and interpretation. The proposed model provides a context for the importance of cultural consideration for activities such as successful managing in a networked world. Nevertheless, while the Hofstede cultural dimension indices cannot be used as a predictable tool for decision making, it can be used as an important tool in knowledge management. The indices indicate that culture differences do exist and those differences can be an important consideration in effective decision 
making. Ongoing research will focus on age, occupational and professional cultural differentials and changes over time.

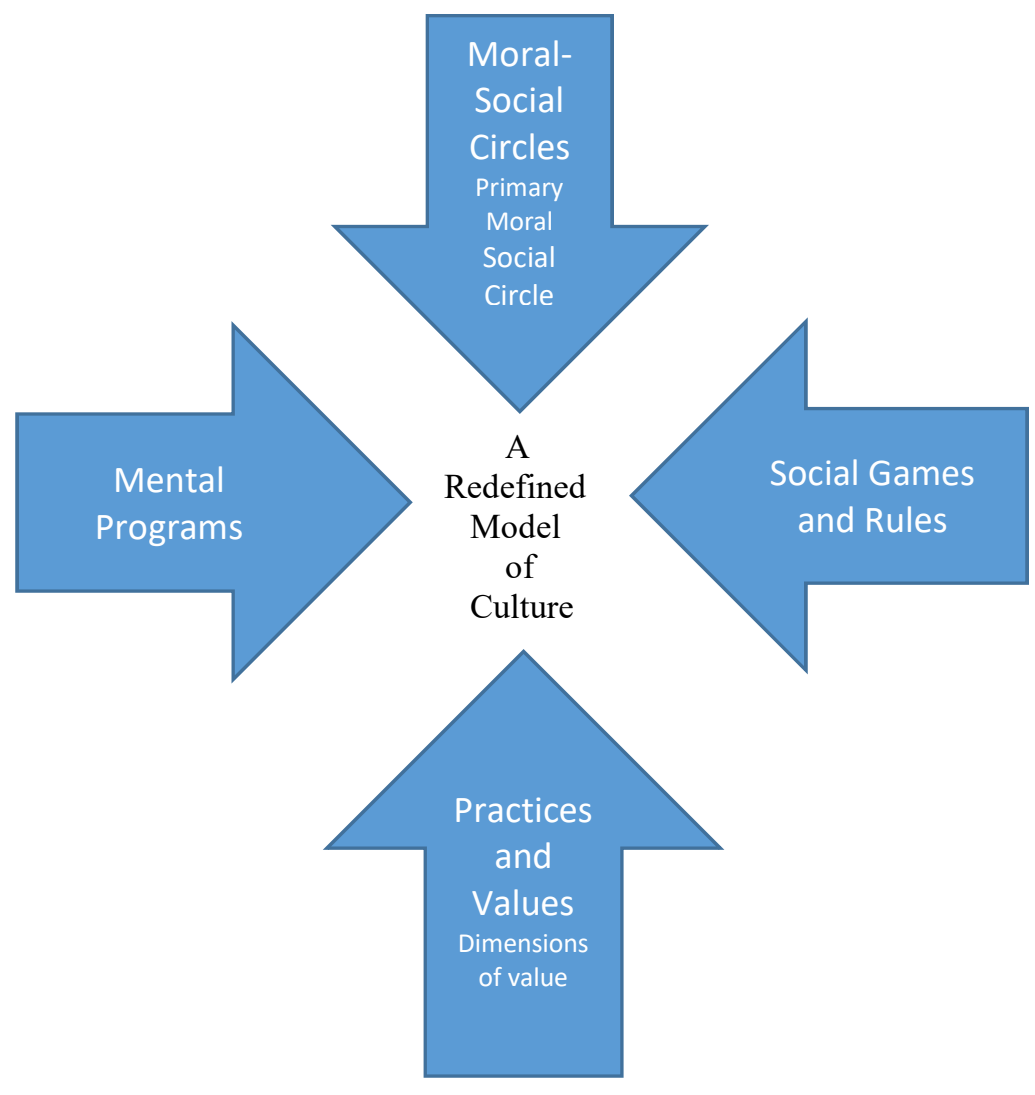

Figure 1. A synthetic conceptual model depicting cultural drivers and attributes

\section{REFERENCES}

Boje, D. M. \&Windsor, R. D. (1993). The resurrection of raylorism: total quality management's hidden agenda. The Journal of Organizational Change Management, 6, 57.

Burčik, V., Kohun, F. \& Skovira, R.J. (2012) Research into hofstede's thesis. Knowledge and Learning: Global Empowerment-Referred Proceedings of the Management, Knowledge and Learning International Conference 2012, 20-22 June 2012, Celje, Slovenia.

Burčik, V., Belanová, A., Delorenzo, G. J., Kohun, F. G., \& Skovira, R. J. (2009). A data driven conceptual analysis of globalization - cultural affects and Hofstedian organizational frames: The Slovak Republic example. Issues in informing science and information technology, 6, 461-468.

Burčik, V, DeLorenzo, G., Kohun, F., \& Skovira, R. (2008). Analysis of cultural effects on business curricular subject matter. Issues in Information Systems, 9(1), 207-216.

Burčik, V., Kohun, F. G., \& Skovira, R. J. (2007). Analyzing the affect of culture on curricular content: A research conception. Issues in Informing Science and Information Technology, 4, 381-393. 
Davenport, T. H., Eccles, R. G., \& Prusak, L. (1992, Fall). Information politics. Sloan Management Review, 34(1), 53-65.

Davenport, T. H. \& L. Prusak. (1997). Information ecology: Mastering the information and knowledge environment. Boston, MA: Harvard Business School Press.

DeLorenzo, G., Kohun, F. \& Skovira, R. J. (2006). Analyzing the affect of globalizing business education on managerial and organizational theories: A framework for research. Proceedings of the 7th International Conference of the Faculty of Management Koper, University of Primorska, Slovenia, 7, 1833-1840.

Drucker, P.F. (1997). The Global Economy and the Nation-State, Foreign Affairs, 76(5).

Hofstede, G. (2001). Culture's consequences: Comparing values, behaviors, institutions, and organizations across nations, Thousand Oaks, CA: Sage.

Hofstede, G. \& Hofstede, G. J. (2005). Cultures and organizations: Software of the mind. New York: McGraw-Hill.

Hofstede, G. \& Hofstede, G. J. \& Minkov, M. (2010). Cultures and organizations, New York: McGraw-Hill.

Hooker, J. (2003). Working across cultures. Stanford, CA: Stanford University Press.

Kohun, F.G., Skovira, R.J, \& Burcik, V. (2012). Research into Hofstede's thesis. knowledge and learning: global empowerment. Referred Proceedings of the Management, Knowledge and Learning International Conference 2012, 20-22.

Kohun, F., Skovira R.J. \& Burčik V (2012). Decision-making in the context of its social-cultural environments: A proposed research model. Issues in Information Systems, 13(2), 320-327.

Kohun, F. G., Skovira, R.J., Burcik, V. \& DeLorenzo G. A research framework revisited: The cultural affect on managerial and organizational theory and curriculum-- Post 2007 global economic crisis. ToKnow Press, http://www.toknowpress.net/ISBN/978-961-6914-02-4/papers/ML13-394.pdf full text (application/pdf)

McSweeny, B. (2003). Is national culture a myth? A critique of the claims of Geert Hofstede. Research Seminar 12 November 2003 at School of Management, Royal Holloway, University of London.

Norman, D. A. (1988). The design of everyday things. New York: Currency Doubleday.

Rowe, A. J. \& Mason, R. O. (1989). Managing with style: a guide to understanding, assessing, and improving decision making. San Francisco London: Jossey-Bass.

Skovira, R. J. (2004). Using informational landscape as a model to understand information use and design within organizations. Issues in Information Systems, 5(1), 308-314. 